\title{
An exploration study on influential factors on information and communication technology
}

\author{
Naser Azad*, Mehdi Nikanpour and Somayeh Hozouri
}

Department of Management, Islamic Azad University, South Tehran Branch, Tehran, Iran

\begin{tabular}{|c|c|}
\hline CHRON I C L E & A B S T R A C T \\
\hline $\begin{array}{l}\text { Article history: } \\
\text { Received January } 15,2013 \\
\text { Accepted August } 12,2013 \\
\text { Available online } \\
\text { August } 142013 \\
\text { Keywords: } \\
\text { Information and communication } \\
\text { technology } \\
\text { ICT } \\
\text { Factor analysis } \\
\text { Banking industry }\end{array}$ & $\begin{array}{l}\text { During the past few years, information and communication technology (ICT) has } \\
\text { revolutionized banking industry in the world. People are now able to do their business banking } \\
\text { activities such as bill payments, transfer funds, etc. through the art of ICT features such as } \\
\text { automatic teller machines, internet or telephone banking services. This paper performs an } \\
\text { empirical investigation to find important factors influencing ICT implementation in Iranian } \\
\text { banking industry. The survey uses factor analysis to find important factors using a } \\
\text { questionnaire consist of } 26 \text { variables. Cronbach alpha is calculated as } 0.901 \text {, which validates the } \\
\text { questionnaire. The survey detects six factors influencing ICT including efficiency approach, } \\
\text { new advanced technological achievements, human resource management, service strategy, } \\
\text { growth strategy and supporting systems. }\end{array}$ \\
\hline
\end{tabular}

\section{Introduction}

Information and communication technology (ICT) plays essential role in banking sector, while banking industry is a real engine of every robust economy. In fact, when banking industry fails to operate properly, the whole economy will be jeopardized. The impact of globalization, competition and innovation in the banking industry by its providers to offer their services makes it necessity to realize how different perspectives of consumer behavior influence the innovation and respond to customer service delivery (Van den Berg et al., 2008; Mohamed \& Moradi, 2011). Abubakar and Tasmin (2012) performs an investigation to review the literature with an objective to investigate the effect of ICT on banks performance and customer service delivery. They also examined the effect of ICT on banks' performance to verify whether banks have successfully reached effective customer's service delivery, by providing high level of customer service through online delivery channel, besides operating cost minimization and revenue maximization.

* Corresponding author

E-mail addresses: dr.naserazad@yahoo.com (N. Azad)

(C) 2013 Growing Science Ltd. All rights reserved. doi: $10.5267 /$ j.ds1.2013.08.005 
Banking industry has become highly ICT based and due to its inter-sectoral link, it is reaping the advantages of technological revolution as evidenced by its application in most of its operations. Osabuohien (2008) performed an empirical investigation of the anticipated role ICT has in enhancing the operations of some selected Nigerian banks. They stated that the need for the banks to regularly train their workers, and procure quality ICT gadgets, which would enhance efficiency was necessary to improve the banking sector. An implementation of other useful techniques such as Six Sigma could also improve profitability (Shoebridge, 2005).

Vilaseca-Requena et al. (2007) looked to explore the role that ICT played in the processes of product innovation and marketing - as an element that strengthens the cooperation and communication among various agents within the innovation project, reducing the barriers to innovation and enhancing the development of differentiated products as well. They stated that intensive ICT implementation in marketing makes the company more innovative, as it perceives that its usage breaks down obstacles to innovation and speeds up processes that in turn become more productive. In addition, increasing ICT implementation in marketing helps company predisposition to cooperate with and integrate particular agents within the business environment in the business development using innovation process, improving the degree of adaptation of the new product to market demands.

Agbolade (2011) investigated the role of ICT to increase banks profitability in Nigeria. He explained that the role of information in the actualization of different organizational objectives could not be over-emphasized. They reported that a positive correlation exists between ICT and banks profitability in Nigeria, which means that a marginal change in the level of the investment and adoption of ICT in the banking industry will yield to a proportionate increase in the profit level. Southard and Siau (2004) performed a comprehensive survey on online e-banking retail initiatives. Sullivan (2000) investigated how the adoption of internet banking influenced performance and risk in banks and discussed that while the existence of such services could contribute to banking industry, there must be some cautious on protecting the customers' information through secure implementation of information technology. Baliamoune-Lutz (2003) performed an analysis of the determinants and effects of ICT diffusion in developing countries.

\section{The proposed study}

This paper performs an empirical investigation to find important factors influencing ICT implementation in Iranian banking industry. The population of this survey includes all regular customers who do banking business with one of Iranian banks named Bank Mellat located in city of Tehran, Iran. The sample size is calculated as follows,

$$
N=Z_{\alpha / 2}^{2} \frac{p \times q}{e^{2}},
$$

where $N$ is the sample size, $p=1-q$ represents the probability, $z_{\alpha / 2}$ is CDF of normal distribution and finally $\varepsilon$ is the error term. For our study we assume $p=0.5, z_{\alpha / 2}=1.96$ and $e=0.99$, the number of sample size is calculated as $N=159$. The survey uses factor analysis to find important factors using a questionnaire consist of 26 variables.

Cronbach alpha has been calculated as 0.891 in preliminary stage and final 0.901 in final stage, which are statistically acceptable. In addition, Kaiser-Meyer-Olkin Measure of Sampling Adequacy is calculated as 0.844 , which is within an acceptable limit and validates the results. Since factor analysis is sensitive on skewness of factors, we have decided to delete 11 questions. Fig. 1 demonstrates Scree plot on questions of the survey. Table 3 demonstrates the results of our factor analysis. 


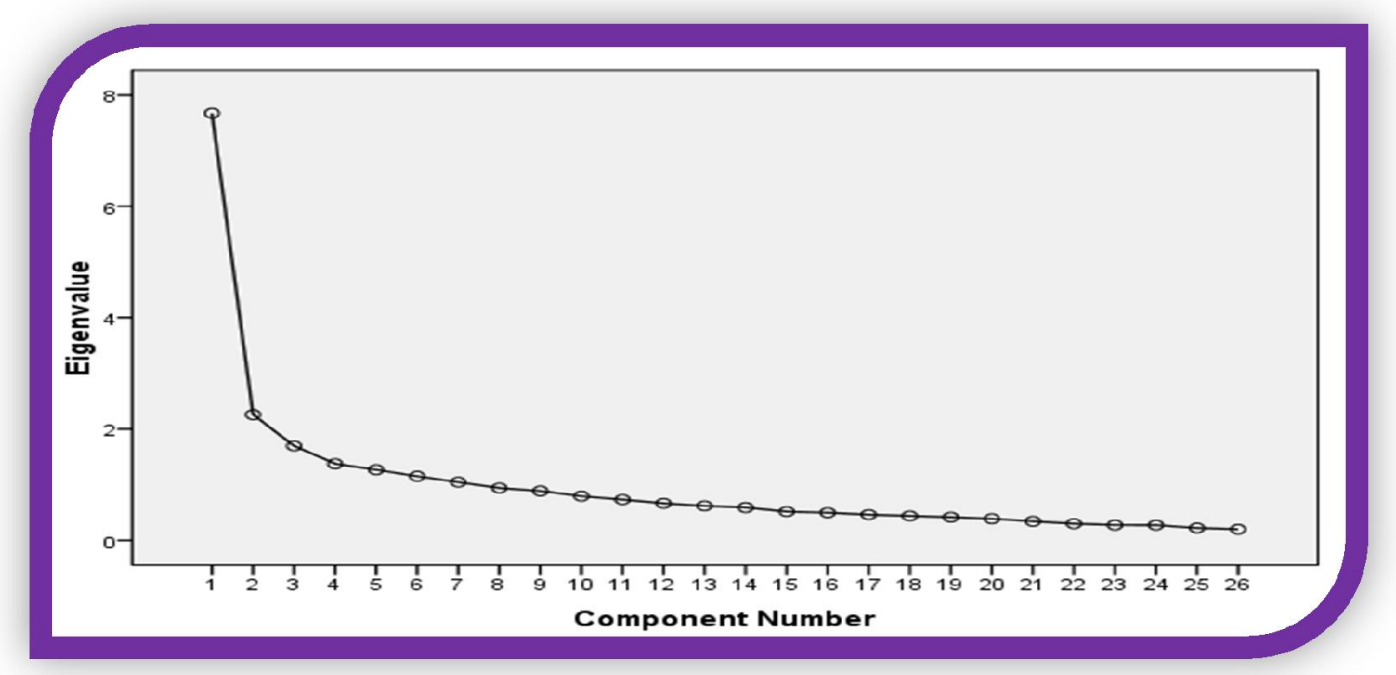

Fig. 1. The results of Scree plot

Table 3

The results of total variance explained

\begin{tabular}{|c|c|c|c|c|c|c|c|c|c|}
\hline & \multicolumn{3}{|c|}{ Initial Eigenvalues } & \multicolumn{3}{|c|}{$\begin{array}{l}\text { Extraction Sums of Squared } \\
\text { Loadings }\end{array}$} & \multicolumn{3}{|c|}{$\begin{array}{c}\text { Rotation Sums of Squared } \\
\text { Loadings }\end{array}$} \\
\hline & Total & $\begin{array}{c}\% \text { of } \\
\text { Variance }\end{array}$ & Cumulative \% & Total & $\begin{array}{c}\% \text { of } \\
\text { Variance }\end{array}$ & $\begin{array}{c}\text { Cumulative } \\
\%\end{array}$ & Total & $\begin{array}{c}\% \text { of } \\
\text { Variance }\end{array}$ & $\begin{array}{c}\text { Cumulative } \\
\%\end{array}$ \\
\hline 1 & 7.675 & 29.519 & 29.519 & 7.675 & 29.519 & 29.519 & 2.800 & 10.769 & 10.769 \\
\hline 2 & 2.257 & 8.680 & 38.199 & 2.257 & 8.680 & 38.199 & 2.767 & 10.641 & 21.411 \\
\hline 3 & 1.695 & 6.520 & 44.719 & 1.695 & 6.520 & 44.719 & 2.707 & 10.410 & 31.820 \\
\hline 4 & 1.374 & 5.284 & 50.003 & 1.374 & 5.284 & 50.003 & 2.537 & 9.759 & 41.580 \\
\hline 5 & 1.267 & 4.874 & 54.877 & 1.267 & 4.874 & 54.877 & 2.308 & 8.878 & 50.458 \\
\hline 6 & 1.151 & 4.426 & 59.303 & 1.151 & 4.426 & 59.303 & 1.934 & 7.438 & 57.897 \\
\hline 7 & 1.045 & 4.018 & 63.321 & 1.045 & 4.018 & 63.321 & 1.410 & 5.424 & 63.321 \\
\hline 8 & .939 & 3.613 & 66.933 & & & & & & \\
\hline 9 & .886 & 3.406 & 70.339 & & & & & & \\
\hline 10 & .792 & 3.047 & 73.386 & & & & & & \\
\hline 11 & .732 & 2.814 & 76.200 & & & & & & \\
\hline 12 & .663 & 2.550 & 78.750 & & & & & & \\
\hline 13 & .618 & 2.377 & 81.128 & & & & & & \\
\hline 14 & .588 & 2.263 & 83.391 & & & & & & \\
\hline 15 & .515 & 1.981 & 85.371 & & & & & & \\
\hline 16 & .496 & 1.908 & 87.279 & & & & & & \\
\hline 17 & .461 & 1.773 & 89.052 & & & & & & \\
\hline 18 & .437 & 1.680 & 90.732 & & & & & & \\
\hline 19 & .416 & 1.600 & 92.332 & & & & & & \\
\hline 20 & .387 & 1.490 & 93.822 & & & & & & \\
\hline 21 & .341 & 1.311 & 95.133 & & & & & & \\
\hline 22 & .299 & 1.150 & 96.283 & & & & & & \\
\hline 23 & .274 & 1.054 & 97.337 & & & & & & \\
\hline 24 & .273 & 1.052 & 98.389 & & & & & & \\
\hline 25 & .220 & .847 & 99.236 & & & & & & \\
\hline 26 & .199 & .764 & 100.000 & & & & & & \\
\hline
\end{tabular}

As we can observe from the results of Fig. 1 and Table 1, there are six factors influencing ICT including efficiency approach, new advanced technological achievements, human resource management, service strategy, growth strategy and supporting systems. 


\section{The results}

In this section, we present details of six influencing factors on ICT implementation.

\subsection{The first factor: efficiency}

The first factor is associated with efficiency strategy, which includes four factors as follows,

\section{Table 2}

The summary of factors influencing efficiency

\begin{tabular}{|c|c|c|c|c|}
\hline Option & Factor weight & Eigenvalue & $\%$ of variance & Accumulated \\
\hline Processing information & .681 & & & \\
\hline Recording customer information & .716 & 2.990 & 42.712 & 42.712 \\
\hline Supporting customer's right & .715 & & & \\
\hline Higher education & .709 & & & \\
\hline
\end{tabular}

As we can observe from the results of Table 2, recording customer information is the most important component followed by supporting their right, hiring highly educated people and processing information.

\subsection{New advanced technological achievements}

The second factor is associated with new advanced technological achievements, which includes four factors summarized in Table 3 as follows,

Table 3

The summary of factors influencing new advanced technological achievements

\begin{tabular}{|c|c|c|c|c|}
\hline Option & Factor weight & Eigenvalue & $\%$ of variance & Accumulated \\
\hline Automated payment systems & .781 & & & \\
\hline SMS alarming services & .807 & 2.562 & 51.241 & 51.241 \\
\hline Capability of accessing digital signature & .668 & & & \\
\hline Distance services & .672 & & & \\
\hline
\end{tabular}

The results of Table 3 indicate that SMS alarming services play important role in accessing advanced technological achievement followed by automated payment systems, distance services and capability of accessing digital signature.

\subsection{Human resource management}

Human resource management is the third factor and it includes four factors summarized in Table 4 as follows,

\section{Table 4}

The summary of factors influencing human resource management

\begin{tabular}{|c|c|c|c|c|}
\hline Option & Factor weight & Eigenvalue & $\%$ of variance & Accumulated \\
\hline Productivity improvement & .709 & & & \\
\hline Information circulation & .710 & & & \\
\hline Removing barrier to reach more innovations & .668 & & & \\
\hline Social network and communications & .660 & & & \\
\hline Potential of having various multi-media & .782 & 1.994 & 49.839 & 49.839 \\
\hline Cooperation on innovative processes & .612 & & & \\
\hline
\end{tabular}

The results of Table 4 indicate that potential of having various multi-media is number one priority followed by information circulation, productivity improvement, removing barrier to reach more innovations and social network and communication. 


\subsection{Service strategy}

The fourth factor is associated with service strategy, which includes three factors summarized in Table 5 as follows,

\section{Table 5}

The summary of factors influencing service strategy

\begin{tabular}{|c|c|c|c|c|}
\hline Option & Factor weight & Eigenvalue & $\%$ of variance & Accumulated \\
\hline Using intranet services & .649 & & & \\
\hline Outsourcing & .764 & 2.289 & 45.777 & 45.777 \\
\hline Email services & .673 & & & \\
\hline
\end{tabular}

The results of Table 5 demonstrate that providing email services is number one priority followed by outsourcing features and using intranet services.

\subsection{Growth opportunities}

The fifth factor is associated with new growth opportunities, which includes four factors summarized in Table 6 as follows,

\section{Table 6}

The summary of factors influencing growth opportunities

\begin{tabular}{|c|c|c|c|c|}
\hline Option & Factor weight & Eigenvalue & $\%$ of variance & Accumulated \\
\hline Scientific research & .607 & & & \\
\hline Web sites & .832 & 1.936 & 48.398 & 48.398 \\
\hline National access to internet & .656 & & & \\
\hline Investment & .744 & & & \\
\hline
\end{tabular}

The results of Table 6 indicate that having efficient websites play important role in accessing growth opportunities followed by investment, national access to internet and scientific research.

\subsection{Supporting systems}

The last factor is related to supporting systems, which includes four factors summarized in Table 7 as follows,

\section{Table 7}

The summary of factors influencing supporting systems

\begin{tabular}{|c|c|c|c|c|}
\hline Option & Factor weight & Eigenvalue & $\%$ of variance & Accumulated \\
\hline Quality of maintenance & .805 & & & \\
\hline Levels of Profitability & .707 & 1.692 & 56.387 & 56.387 \\
\hline Health of internet & .607 & & & \\
\hline Training and learning & .656 & & & \\
\hline
\end{tabular}

The results of Table 7 indicate that quality of maintenance of ICT components is number one priority in supporting systems followed by levels of profitability, training and learning and health of internet.

\section{Conclusion}

In this paper, we have presented an empirical investigation to study the influential factors on implementation of banking industry. The study has explained that ICT has become a primary source of sustainable growth in banking industry. The study has implemented factor analysis to find six important factors including efficiency approach, new advanced technological achievements, human resource management, service strategy, growth strategy and supporting systems. The study has shed 
light on the relative importance of ICT in banking industry. However, ICT implementation may help us reach constructive results when all aspects of ICT such as internet security, infrastructure etc. have been carefully considered.

\section{Acknowledgement}

The authors would like to thank the anonymous referees for constructive comments on earlier version of this paper.

\section{References}

Abubakar, A. A., \& Tasmin, R. B. H. (2012). The impact of information and communication technology on banks' performance and customer service delivery in the banking industry. International Journal of Latest Trends in Finance and Economic Sciences, 2(1).

Agbolade, O. K. (2011). Information and communication technology and banks profitability in Nigeria. Australian Journal of Business and Management Research, 1(4), 102-107.

Baliamoune-Lutz, M. (2003). An analysis of the determinants and effects of ICT diffusion in developing countries. Information Technology for Development, 10(3), 151-169.

Mohamed, I., \& Moradi, L. (2011). A model of e-tourism satisfaction factors for foreign tourists. Australian Journal of Basic and Applied Sciences, 5(12), 877-883.

Osabuohien, E. S. (2008). ICT and Nigerian banks reforms: Analysis of anticipated impacts in selected banks. Global Journal of Business Research, 2(2), 67-76.

Shoebridge, M. (2005). Banking on six sigma to improve service quality a case study: major Australian financial institution. Australian Banking \& Finance, 14(9-10).

Southard, P. B., \& Siau, K. (2004). A survey of online e-banking retail initiatives. Communications of the ACM, 47(10), 99-102.

Sullivan, R. J. (2000). How has the adoption of internet banking affected performance and risk in banks?. Financial Industry Perspectives, (Dec), 1-16.

Van den Berg, P., Arentze, T., \& Timmermans, H. (2008). Social networks, ICT use and activitytravel patterns. In Data collection and first analyses. Paperpresented at the 9th International Conference on Design \& Decision Support Systems in Architecture and Urban Planning, The Netherlands.

Vilaseca-Requena, J., Torrent-Sellens, J., \& Jiménez-Zarco, A. I. (2007). ICT use in marketing as innovation success factor: Enhancing cooperation in new product development processes. European Journal of Innovation Management, 10(2), 268-288. 